\title{
Ekstraksi Pektin dari Kulit Jeruk dan Kulit Pisang sebagai Biosorben pada Proses Adsorpsi Logam Berat Fe
}

\author{
Widya Putri Rahayu ${ }^{1}$, Indah Wulan Harisma ${ }^{2}$, Yanna Syamsuddin ${ }^{3 *}$, Sofyana ${ }^{4}$, Sri Mulyati ${ }^{5}$ \\ 1,2,3,4,5 Program Studi Teknik Kimia, Fakultas Teknik, Universitas Syiah Kuala, Banda Aceh \\ *Koresponden email: yanna_syamsuddin@unsyiah.ac.id
}

Disetujui: 30 Maret 2021

\begin{abstract}
One of the alternatives in the treatment of waste containing heavy metals is the use of natural materials as adsorbents, which is known as the biosorption process Pectin is one of the components found in plant cell wall compounds which contain many active groups that plays a key role in the biosorption process which can be used as biosorbents. In this research, the raw materials for pectin resources were orange peel and banana peel. The effectiveness of pectin for both ingredients will be analyzed on the basis of 2 variables, namely the length of contact time $(60,90,120$, and 150 minutes) and the mass of pectin used $(20,30,40$, and $50 \mathrm{mg})$. The pectin of orange and banana peel was proven by Fourier Transform Infrared (FTIR) analysis shown by $\mathrm{C}=\mathrm{O}$ functional group of aldehyde and carboxylic acid compounds. The results of this study indicated that the optimum condition was 150 minutes contact with the addition of $50 \mathrm{mg}$ pectin giving the best adsorption efficiency for orange peel pectin of $88,096 \%$ and banana peel pectin of $99,428 \%$. From the isothermal analysis, the Langmuir and Freundlich isotherms can be applied to the adsorption of Fe metals using orange peel and banana peel pectin with a coefficient of determination of $\mathrm{R} 2 \geq 0.9$.
\end{abstract}

Keywords: adsorbent, biosorbent, pectin, heavy metal, Fe.

\begin{abstract}
Abstrak
Salah satu alternatif dalam pengolahan limbah yang mengandung logam berat adalah penggunaan bahan alam sebagai adsorben, yang disebut sebagai proses biosorpsi. Pektin merupakan salah satu komponen yang terdapat pada salah satu senyawa dinding sel tumbuhan yang banyak mengandung gugus aktif yang berperan penting dalam proses biosorpsi sehingga dapat digunakan sebagai biosorben. Pada penelitian ini digunakan sumber bahan baku pembuatan pektin berupa kulit jeruk dan kulit pisang kepok yang akan digunakan sebagai biosorben logam Fe. Analisa efektivitas pektin dari kedua bahan dilakukan berdasarkan 2 variabel yaitu lamanya waktu kontak $(60,90,120$, dan 150 menit) dan massa pektin yang digunakan $(20,30,40$, dan $50 \mathrm{mg})$. Kandungan pektin pada kulit jeruk dan kulit pisang dibuktikan dari hasil analisis Fourier Transform Infrared (FTIR) yang ditunjukkan dengan adanya gugus fungsi $\mathrm{C}=\mathrm{O}$ yang berupa senyawa aldehid dan senyawa asam karboksilik. Berdasarkan hasil analisis Atomic Adsorption Spectrophotometer (AAS) menunjukkan bahwa kondisi optimum yaitu pada waktu kontak 150 menit dengan penambahan massa pektin $50 \mathrm{mg}$ dengan efisiensi adsorpsi untuk pektin kulit jeruk sebesar 88,096\% dan untuk pektin kulit pisang sebesar 99,428\%. Dari analisa isotherm adsorbsi, isotherm Langmuir dan Freundlich dapat diterapkan pada adsorpsi logam Fe menggunakan pektin kulit jeruk dan kulit pisang dengan nilai koefisien determinasi $\mathrm{R}^{2} \geq 0,9$.
\end{abstract}

Kata kunci: adsorben, biosorben, pektin, logam berat, logam Fe.

\section{Pendahuluan}

Kontaminasi logam berat merupakan masalah serius yang dihadapi saat ini karena logam berat merupakan unsur logam yang sangat berbahaya. Berdasarkan Ref. [1] air lindi Tempat Pembuangan Akhir (TPA) sampah Banda Aceh mengandung logam berat besi (Fe) dengan konsentrasi mencapai 10,9191 ppm. Menurut peraturan KEMENKES Nomor 32 Tahun 2017 menyatakan bahwa standar baku mutu kadar besi $(\mathrm{Fe})$ untuk media air untuk keperluan higiene sanitasi adalah $1 \mathrm{mg} / \mathrm{L}$. Sehingga dapat diartikan bahwa pencemaran logam berat Fe sudah diatas ambang baku mutu. Sejumlah teknik telah dilakukan untuk menurunkan kandungan beberapa logam berat dalam air lindi TPA. Penanganan yang biasa dilakukan umumnya berupa pengendapan secara kimia, penukaran ion, pemisahan dengan membran, dan ekstraksi dengan solvent. Namun, proses-proses tersebut kurang efektif dikarenakan efisiensi yang rendah, kondisi operasi yang sensitif, dan biaya yang relatif mahal. Diantara berbagai alternatif pengolahan limbah logam berat, pengolahan menggunakan biosorben memiliki kelebihan, yaitu 
biaya yang relatif murah, efisiensi yang tinggi pada larutan encer, serta kemudahan proses regenerasinya [2].

Pektin merupakan senyawa polimer dari asam D-galakturonat yang terdapat pada dinding sel tumbuhan yang dihubungkan oleh ikatan 1,4 glikosidik dan banyak terdapat pada lamella tengah dinding sel. Pada dasarnya pektin banyak dimanfaatkan dalam industri makanan, farmasi, dan kosmetik sebagai bahan pembentuk gel. Namun pada struktur komponen pektin juga banyak terdapat gugus aktif, sehingga pektin dapat digunakan sebagai biosorben [3].

Pektin mengandung gugus karboksilat yang dapat mengikat ion logam berat sehingga membentuk senyawa kompleks yang tidak larut dalam air dan dapat digunakan sebagai biosorben logam berat. Reaktivitas pektin sebagai biosorben logam berat sangat bergantung pada derajat esterifikasinya [4]. Berdasarkan derajat esterifikasinya pektin terbagi dua yaitu pektin metoksil rendah dengan kadar metoksil kurang dari 50\% dan apabila kadar metoksil lebih dari 50\% maka pektin tergolong ke dalam pektin metoksil tinggi [5]. Pektin terdapat pada salah satu senyawa dinding sel tumbuhan darat terutama pada buah-buahan, seperti kulit jeruk, kulit cokelat, papaya, apel, wortel, kulit pisang, alpukat, dan lain-lainnya [6]. Kulit jeruk sangat banyak terdapat pada lingkungan sekitar yang apabila tidak diolah hanya akan menjadi sampah yang mencemari lingkungan. Sementara pada kulit jeruk terdapat kandungan pektin yang cukup tinggi. Pektin pada kulit jeruk termasuk pektin bermetoksil rendah, sehingga dapat digunakan sebagai biosorben [3]. Dari penelitian yang pernah dilakukan sebelumnya diketahui bahwa kulit pisang dan jeruk memiliki daya serap yang tinggi terhadap logam berat. Sehingga, pada penelitian ini dilakukan perbandingan efektivitas daya serap logam $\mathrm{Fe}$ dari kulit jeruk dan kulit pisang. Hasil penelitian ini diharapkan dapat digunakan sebagai alternatif dalam penanganan limbah logam berat pada TPA Banda Aceh.

\section{Metode Penelitian}

\section{Tempat dan Waktu Penelitian}

Penelitian ini dilaksanakan pada bulan Maret hingga November 2020 di Laboratorium Proses Teknik Kimia Fakultas Teknik Universitas Syiah Kuala dan analisa dilakukan di Laboratorium Lingkungan Fakultas Teknik Universitas Syiah Kuala.

\section{Alat dan Bahan}

Alat-alat yang digunakan antara lain timbangan digital, pipet tetes, erlenmeyer, gelas ukur, beaker glass, kertas lakmus, termometer, blender, kertas saring, shaker, oven, buret, corong kaca, Fourier Transform InfraRed (FTIR) Shimadzu 8400s, Atomic Absorption Spectrofotometer (AAS). Bahan-bahan yang digunakan dalam penelitian ini antara lain kulit jeruk dan kulit pisang yang diperoleh dari penjual jeruk peras dan pisang goreng di Darussalam, $\mathrm{HCl} 1 \mathrm{~N}$, etanol 96\%, Larutan Fe standar, dan aquades.

\section{Prosedur Penelitian}

\section{Pembuatan Biosorben (Citrus sinensis)}

Kulit jeruk manis dihaluskan dengan blender hingga menjadi bubur pektin, kemudian ditimbang sebanyak $100 \mathrm{~g}$ bubur pektin ditambahkan $\mathrm{HCl} 1 \mathrm{~N}$ hingga $\mathrm{pH}$ menjadi 1,5. Bubur pektin asam dipanaskan pada suhu $80^{\circ} \mathrm{C}$ selama 80 menit. Campuran yang diperoleh kemudian disaring untuk memisahkan filtrat dan endapan. Filtrat yang diperoleh didiamkan hingga suhu ruangan, lalu ditambahkan etanol dengan perbandingan etanol : $\mathrm{HCl}$ yaitu 2:1 selama $19 \mathrm{jam}$. Endapan yang terbentuk disaring dan dicuci menggunakan etanol $96 \%$, kemudian dikeringkan pada suhu $40^{\circ} \mathrm{C}$ selama 8 jam menggunakan oven. Hasil yang diperoleh selanjutnya dianalisa kandungan pektin yang terbentuk dengan menggunakan FTIR.

\section{Waktu Kontak}

Pektin kulit jeruk (Citrus sinensis) dengan massa $20 \mathrm{mg}$ dikontakkan dengan $20 \mathrm{~mL}$ larutan logam $\mathrm{Fe} 12 \mathrm{mg} / \mathrm{L}$. Kemudian larutan Fe di shaker dengan kecepatan $230 \mathrm{rpm}$ dengan variasi waktu 60, 90,1 20, dan 150 menit. Pektin yang telah di shaker kemudian disaring menggunakan kertas saring. Larutan Fe yang diperoleh kemudian di uji menggunakan AAS.

\section{Massa Biosorben}

Pektin kulit jeruk(Citrus sinensis) dengan massa 20, 30, 40, dan 50 mg masing-masing dikontakkan dengan $20 \mathrm{~mL}$ logam Fe $12 \mathrm{mg} / \mathrm{L}$. Kemudian larutan Fe di shaker dengan kecepatan $230 \mathrm{rpm}$ dengan waktu kontak optimum. Pektin yang telah di shaker selanjutnya dipisahkan dari larutan Fe dengan menggunakan kertas saring. Larutan Fe yang diperoleh kemudian dilakukan pengujian menggunakan AAS. 


\section{Teknik Analisis Data}

a. Yield

Pektin kulit jeruk yang dihasilkan kemudian dihitung nilai yield menggunakan persamaan 1:

$$
\text { Yield pektin }(\%)=\frac{\mathrm{w}_{\mathrm{O}}}{\mathrm{W}} \times 100
$$

Dimana: $\quad \mathrm{w}_{\mathrm{o}}=$ berat pektin kulit jeruk yang diperoleh

$\mathrm{W}=$ berat bahan baku kulitk jeruk

b. Studi Isoterm

Data logam Fe pada proses adsorpsi menggunakan pektin kulit jeruk yang diperoleh dari Atomic Adsorption Spectrofotometer dapar dihitung menggunakan persamaan Freundlich dan Langmuir sebagai berikut [7]:

Persamaan Freudnlich

Dimana:

$$
\frac{C e}{q_{e}}=\frac{1}{q_{m K_{l}}}+\frac{1}{q_{m}} C_{e}
$$

$\mathrm{Ce} \quad=$ kosentrasi adsorbat dalam larutan $(\mathrm{mg} / \mathrm{L})$

qe $\quad=$ kosentrasi adsorbat yang terserap per gram adsorben $(\mathrm{mg} / \mathrm{g})$

$\mathrm{qm} \quad=$ kapasitas adsorpsi lapisan tunggal $(\mathrm{mg} / \mathrm{g})$

$\mathrm{Kl}=$ konstanta isotherm $(\mathrm{L} / \mathrm{mg})$

Persamaan Langmuir

$$
\begin{aligned}
\log q_{e} & =\log K_{f}+(1 / n) \log C_{e} \\
\log q e & =\log K f+(1 / n) \log C e
\end{aligned}
$$

Dimana:

Kf $\quad=$ konstanta isotherm Freundlich $(\mathrm{mg} / \mathrm{g})$

$1 / \mathrm{n} \quad=$ konstanta indikatif yang menunjukan intensitas proses adsorpsi

\section{Hasil dan Pembahasan}

\section{Analisis Uji FTIR Pektin Kulit Jeruk dan Kulit Pisang}

Analisis Spectroscopy Fourier Transform Infrared merupakan suatu instrument yang dapat mengidentifikasi ikatan kimia dengan menggunakan spektrum infrared yang diserap oleh material secara fungsional pada frekuensi tertentu [7]. Analisa pektin menggunakan FTIR bertujuan untuk mengidentifikasi gugus-gugus fungsi pektin dari hasil isolasi berdasarkan serapan bilangan gelombang yang diperoleh lalu dibandingkan dengan serapan gelombang pektin standar. Dimana analisa digunakan untuk mengidentifikasi derajat esterifikasi gugus fungsional dari pektin berupa COOR, ester, COO-, dan karboksilat [10]. Grafik pembacaan spektrum FTIR pada pektin standar dengan pektin hasil isolasi dari kulit jeruk dapat dilihat pada Gambar 1 dan Gambar 2. Berdasarkan Gambar 1 dan Gambar 2 dapat dilihat perbandingan antara spektrum FTIR pektin standar dan spektrum FTIR pektin hasil isolasi kulit jeruk dan kulit pisang dengan membandingkan serapan bilangan gelombang yang muncul sebagaimana terlihat pada Tabel 1. 


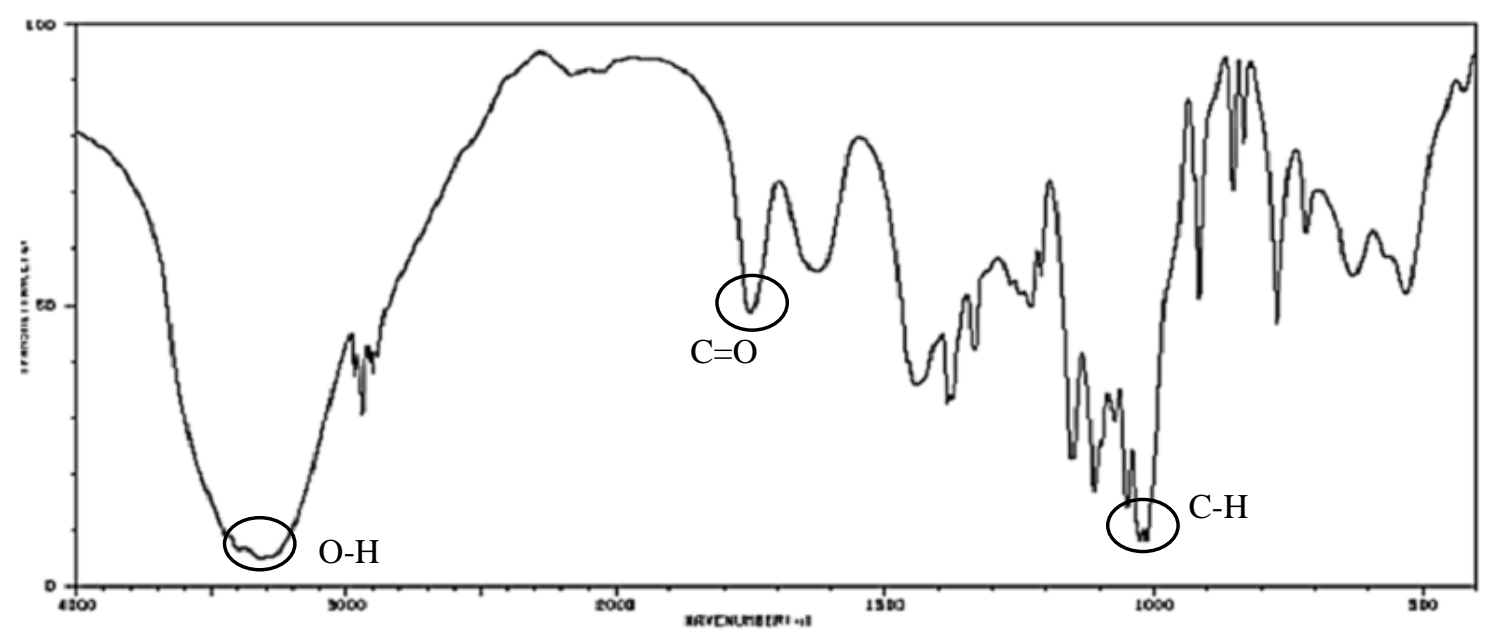

Gambar 1. Spektrum FTIR pektin standar Sumber: Ref. [9]

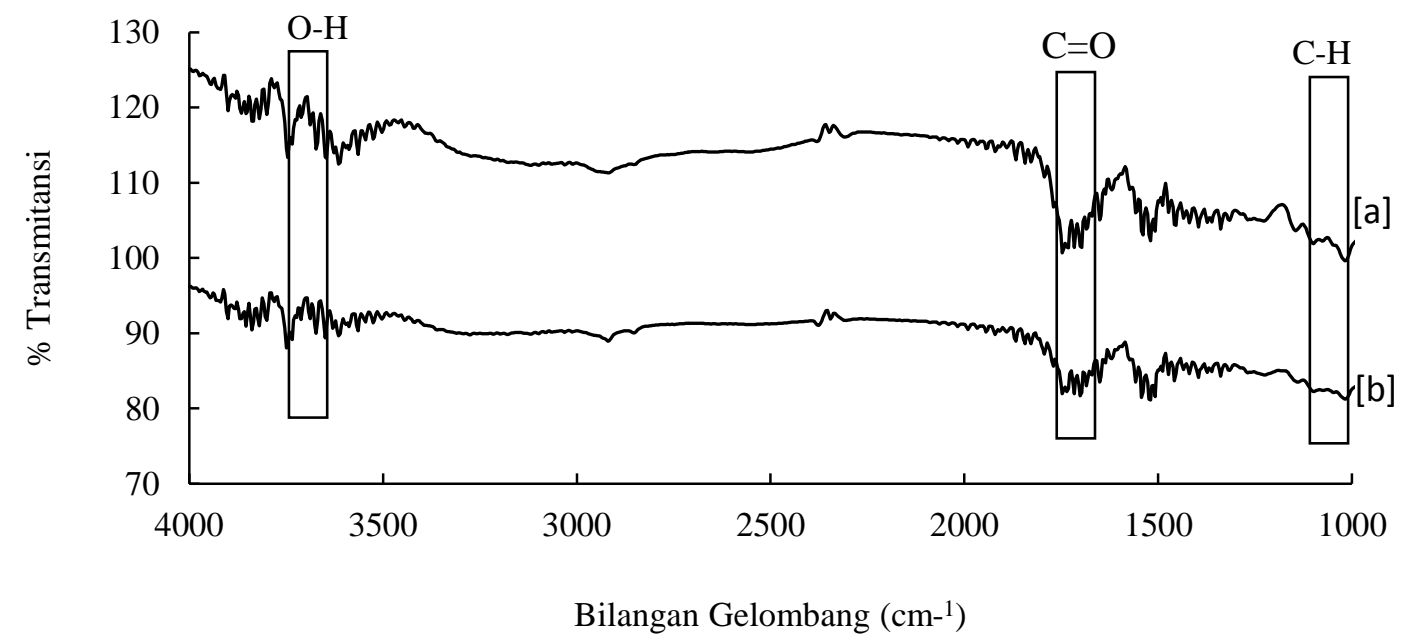

Gambar 2. Spektrum FTIR pektin dari kulit pisang (a) dan kulit jeruk (b)

Sumber: Hasil pengujian penelitian, (2020)

Tabel 1. Hasil pembacaan spektrum FTIR pektin kulit jeruk dan kulit pisang

\begin{tabular}{|c|c|c|}
\hline Ikatan & Jenis atau Gugus Senyawa & Kisaran Frekuensi $\left(\mathrm{cm}^{-1}\right)$ \\
\hline $\mathrm{O}-\mathrm{H}$ & Alkohol & $3650-3600$ \\
\hline \multirow{2}{*}{$\mathrm{C}=\mathrm{O}$} & Aldehid & $1740-1720$ \\
\hline & Asam Karboksilik & $1725-1700$ \\
\hline $\mathrm{C}=\mathrm{C}$ & Aromatik & $1600-1475$ \\
\hline \multirow{2}{*}{$\mathrm{CH}$} & $\mathrm{CH}_{3}$ & $1450-1375$ \\
\hline & Alkena & $1000-650$ \\
\hline $\mathrm{C}-\mathrm{O}$ & Alkohol, ether, ester, As. Karbosilik & $1300-1000$ \\
\hline
\end{tabular}

\section{Pengaruh Waktu Kontak}

Efisiensi adsorpsi pada penelitian ini merupakan persentase ion logam Fe yang teradsorpsi oleh pektin dari kulit jeruk dan kulit pisang pada waktu kontak 60, 90, 120 dan 150 menit. Efisiensi dapat dihitung menggunakan persamaan:

$$
\% \text { Efisiensi }=\frac{C_{0}-C_{e}}{C_{0}} \times 100 \%
$$


Dimana $\mathrm{C}_{0}$ adalah konsentrasi awal sebelum terjadi proses adsorpsi $(\mathrm{mg} / \mathrm{L})$ dan Ce merupakan konsentrasi akhir setelah terjadinya proses adsorpsi $(\mathrm{mg} / \mathrm{L})$ pada waktu kontak tertentu.

Tabel 2. Penyerapan logam Fe oleh pektin dengan waktu kontak 150 menit

\begin{tabular}{ccccc}
\hline A & Massa (gram) & $\mathrm{Ct}(\mathrm{mg} / \mathrm{L})$ & Kapasitas penyerapan $(\mathrm{mg} / \mathrm{g})$ & Efisiensi (\%) \\
\hline & 0,02 & 6 & 6 & 50 \\
Kulit jeruk (Citrus & 0,03 & 2,9714 & 6,0191 & 75,238 \\
sinensis) & 0,04 & 2,5428 & 4,7286 & 78,81 \\
& 0,05 & 1,4285 & 4,2286 & 88,096 \\
\hline $\mathrm{A}$ & Massa (gram) & $\mathrm{Ct}(\mathrm{mg} / \mathrm{L})$ & Kapasitas penyerapan $(\mathrm{mg} / \mathrm{g})$ & Efisiensi (\%) \\
\hline & 0,02 & 3,4386 & 8,5614 & 71,345 \\
Kulit Pisang (Musaceaea sp.) & 0,03 & 8,6286 & 2,2476 & 28,095 \\
& 0,04 & 7,7714 & 2,1143 & 35,238 \\
& 0,05 & 0,0686 & 4,7726 & 99,428 \\
\hline
\end{tabular}

Sumber: Hasil pengujian penelitian, (2020)

Adapun untuk grafik efektivitas penyerapan logam Fe menggunakan pektin kulit jeruk dan kulit pisang dengan penambahan massa pektin $20 \mathrm{mg}$ dapat dilihat pada Gambar 3. Berdasarkan Gambar 3 terlihat bahwa penambahan pektin kulit jeruk dan kulit pisang dengan waktu kontak 60, 90, 120, dan 150 menit didapatkan nilai efisiensi adsorpsi sebesar 35,714; 40,476; 81,191; dan 50\% untuk kulit jeruk.

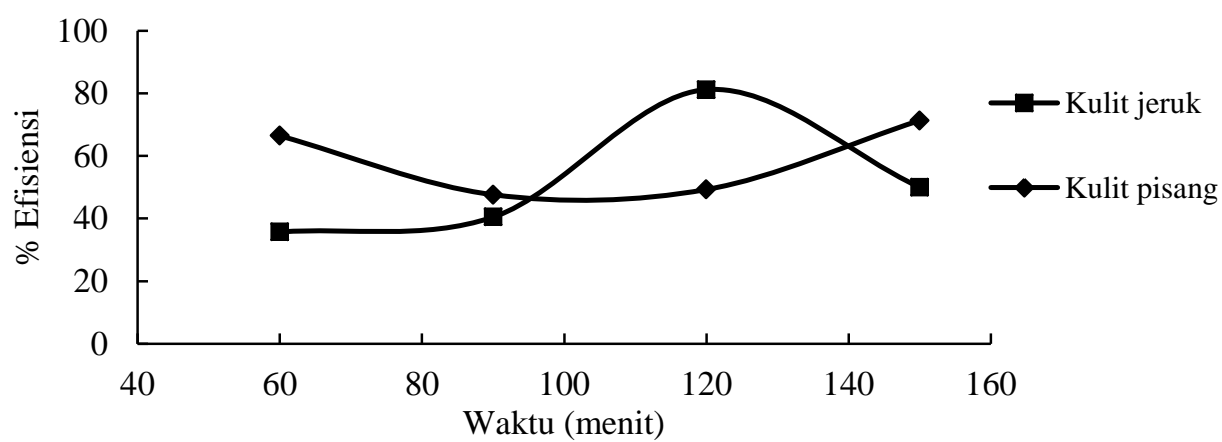

Gambar 3. Pengaruh waktu kontak terhadap efisiensi adsorpsi Sumber: Hasil pengujian penelitian, (2020)

Sedangkan pada penambahan pektin kulit pisang dengan waktu kontak yang sama didapatkan nilai persentase efisiensi adsorpsi sebesar 66,429; 47,619; 49,286; dan 71,345\%. Efisiensi adsorpsi meningkat pesat pada waktu kontak 120 menit yang kemudian mengalami penurunan pada waktu kontak 150 menit. Hal ini disebabkan karena terjadinya proses desorpsi. Menurut Ref. [11], penurunan persen efisiensi adsorpsi terjadi karena permukaan adsorben yang telah jenuh sehingga tidak dapat berikatan dengan logam Fe (II) sehingga menyebabkan terjadinya proses desorpsi. Waktu kontak antara logam ion dengan adsorben sangat mempengaruhi efisiensi penyerapan. Semakin lama waktu kontak antara ion logam dengan adsorben maka daya serap logam juga semakin tinggi hinga mencapai waktu optimum [3].

Pengaruh Massa

Pada penelitian ini dilakukan variasi penambahan massa pektin yaitu $20 \mathrm{mg}, 30 \mathrm{mg}, 40 \mathrm{mg}$, dan 50 $\mathrm{mg}$, pada kondisi $\mathrm{pH}$ dan temperatur tetap dengan waktu kontak 150 menit.

Tabel 3. Penyerapan logam Fe oleh pektin dengan massa adsorben 0,02 gram

\begin{tabular}{|c|c|c|c|c|}
\hline A & Waktu (menit) & $\mathrm{Ct}(\mathrm{mg} / \mathrm{L})$ & Kapasitas penyerapan $(\mathrm{mg} / \mathrm{g})$ & Efisiensi (\%) \\
\hline \multirow{4}{*}{ Kulit jeruk (Citrus sinensis) } & 60 & 7,7143 & 4,286 & 35,714 \\
\hline & 90 & 7,1429 & 4,857 & 40,476 \\
\hline & 120 & 2,2571 & 9,743 & 81,191 \\
\hline & 150 & 6,0000 & 6 & 50 \\
\hline \multirow{2}{*}{ Kulit Pisang (Musaceaea sp.) } & 60 & 4,0285 & 7,972 & 66,429 \\
\hline & 90 & 6,2857 & 5,714 & 47,619 \\
\hline A & Waktu (menit) & $\mathrm{Ct}(\mathrm{mg} / \mathrm{L})$ & Kapasitas penyerapan $(\mathrm{mg} / \mathrm{g})$ & Efisiensi (\%) \\
\hline \multirow{2}{*}{ Kulit Pisang (Musaceaea sp.) } & 120 & 6,0857 & 5,914 & 49,286 \\
\hline & 150 & 3,4386 & 8,561 & 71,345 \\
\hline
\end{tabular}

Sumber: Hasil pengujian penelitian, (2020) 
Adapun untuk grafik efektivitas penyerapan logam Fe menggunakan pektin kulit jeruk dan kulit pisang dengan waktu kontak 150 menit dapat dilihat pada Gambar 4.

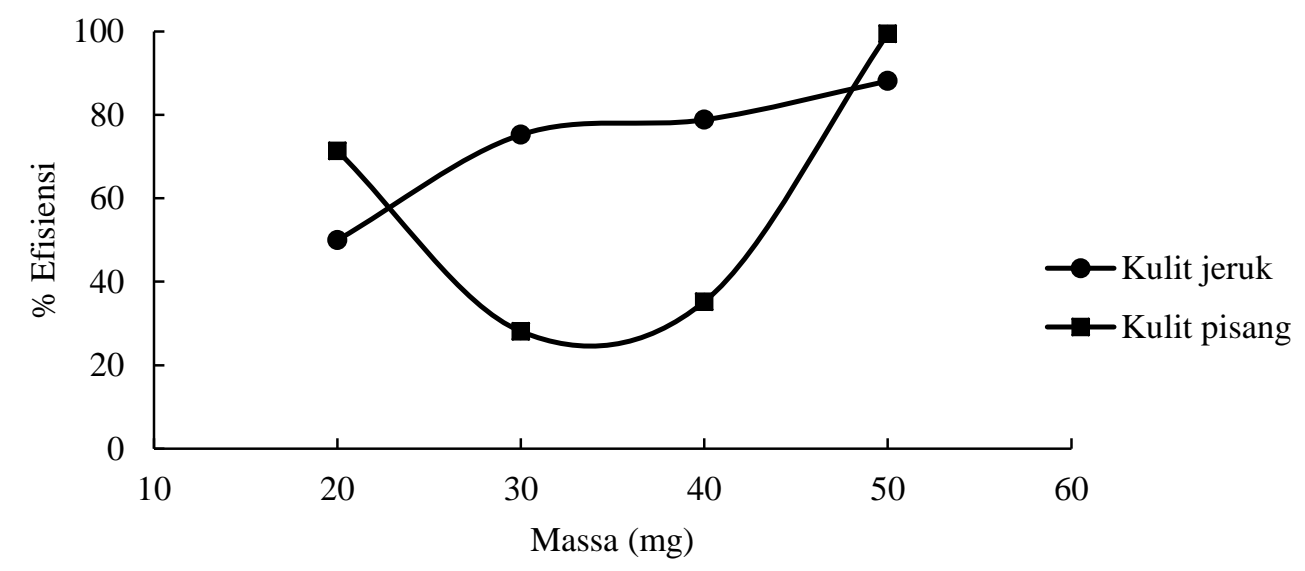

Gambar 4. Pengaruh massa pektin terhadap efisiensi adsorpsi Sumber: Hasil pengujian penelitian, (2020)

Pada Gambar 4 dapat dilihat pengaruh penambahan massa pektin terhadap efisiensi adsorpsi. Pada penambahan massa pektin kulit jeruk sebanyak 20, 30, 40, dan $50 \mathrm{mg}$ didapat nilai efisiensi sebesar 50; 75,238; 78,81; dan 88,096\%. Dari data tersebut dapat dilihat semakin banyak massa pektin yang ditambahkan maka efisiensi adsorpsi logam Fe semakin meningkat. Berdasarkan Ref. [12] menyatakan semakin banyak adsorben yang digunakan maka ion logam yang teradsorpsi juga semakin banyak. Sedangkan pada grafik pektin kulit pisang dengan penambahan massa sebanyak 20, 30, 40, dan $50 \mathrm{mg}$ didapat nilai efisiensi adsorpsi sebesar 71,$345 ; 28,095 ; 35,238$; dan 99,428\%. Dari data tersebut dapat dilihat bahwa efisiensi adsorpsi mengalami penurunan pada penambahan massa pektin kulit pisang 30 dan $40 \mathrm{mg}$. Tetapi, pada penambahan massa $50 \mathrm{mg}$ efisiensi adsorpsi logam Fe terjadi peningkatan secara drastis. Hal ini kemungkinan terjadi karena pada penambahan massa pektin kulit pisang 30 dan $40 \mathrm{mg}$, ion logam Fe belum sepenuhnya terikat dengan adsorben. Sehingga pada penambahan massa pektin kulit pisang $50 \mathrm{mg}$ efisiensi adsorpsi kembali meningkat [13].

Ref. [14] menyatakan bahwa penambahan adsorben akan meningkatkan sisi aktif sehingga efisiensi adsorpsi akan meningkat, namun sisi aktif tersebut saling berkompetisi dalam penyerapan adsorbat. Secara umum proses adsorpsi terjadi pada semua permukaan, namun untuk efisiensi penyerapan adsorpsi sendiri dipengaruhi oleh luas permukaan yang kontak secara langsung dengan adsorbat. Besarnya adsorpsi berbanding lurus dengan luas permukaan, makin besar luas permukaan maka semakin banyak ion logam yang teradsorpsi [15].

\section{Isoterm Adsorpsi}

Isoterm adsorpsi merupakan hasil percobaan adsorpsi statis dimana adsorben dan adsorbat dikontakkan selama waktu tertentu sehingga mencapai kesetimbangan [16]. Dalam isoterm adsorpsi proses tersebut digambarkan dengan sebuah persamaan atau rumus. Isoterm adsorpsi yang umum digunakan adalah isoterm Freundlich dan isoterm Langmuir. Grafik isoterm Langmuir ion logam Fe dapat diperoleh dengan cara membuat kurva hubungan antara Ce terhadap Ce/qe, sedangkan grafik isoterm Freundlich ion logam $\mathrm{Fe}$ dapat diperoleh dengan cara membuat kurva hubungan antara log $\mathrm{Ce}$ terhadap log qe [17]. 


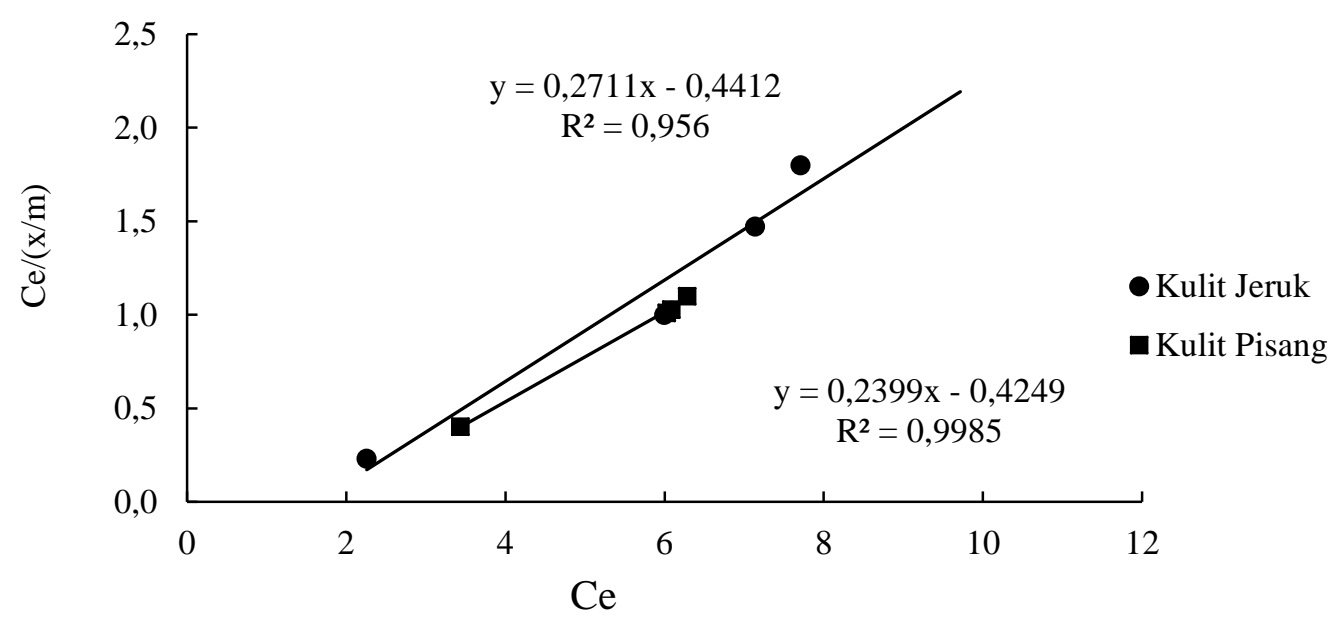

Gambar 5. Kurva Isoterm Langmuir logam Fe dengan adsorben pektin kulit jeruk Sumber: Hasil pengujian penelitian, (2020)

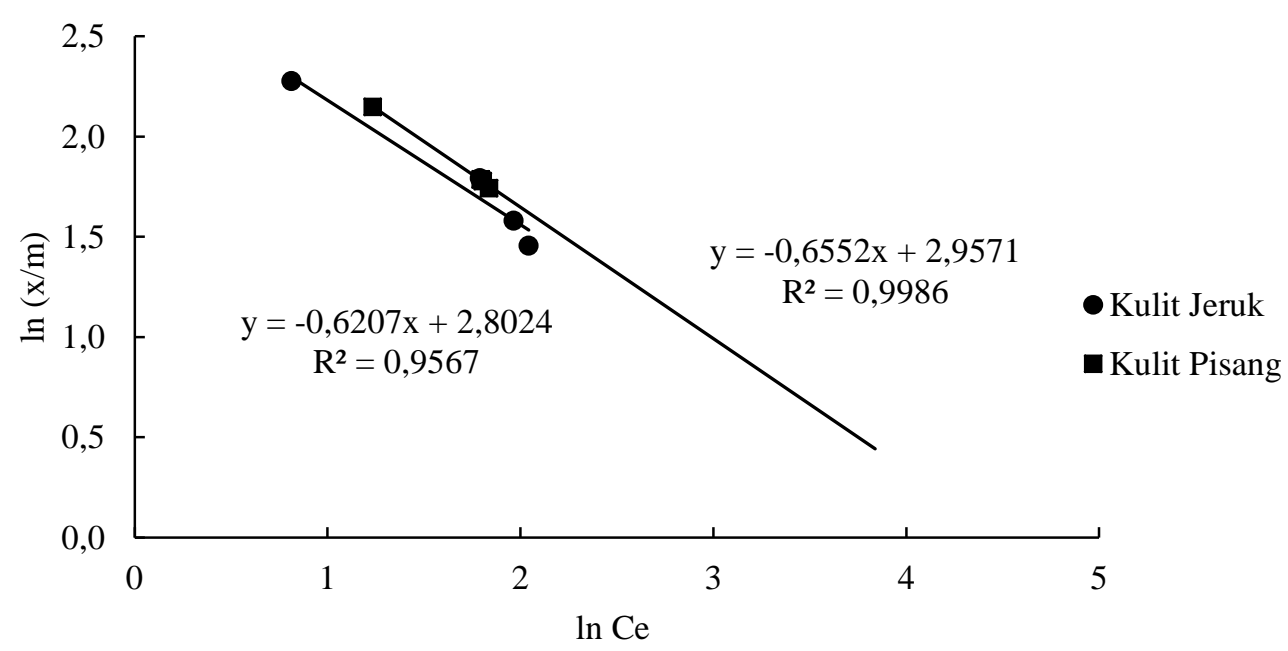

Gambar 6. Model Isoterm Freundlich logam Fe dengan adsorben pektin kulit jeruk Sumber: Hasil pengujian penelitian, (2020)

Pengujian persamaan adsorpsi Langmuir dan juga persamaan Freundlich dibuktikan dengan nilai koefesien determinasi R2 $\geq 0,9$ [18]. Pada Gambar 5 dan Gambar 6 didapat koefesien determinasi R2 isoterm Langmuir untuk kulit jeruk dan kulit pisang yaitu 0,956 dan 0,9985, sedangkan koefesien determinasi R2 untuk isotherm Freundlich yaitu 0,9567 dan 0,9986. Hal ini menunjukkan bahwa persamaan Langmuir dan Freundlich dapat diterapkan pada proses adsorpsi logam Fe.

Tabel 4. Hasil perhitungan isoterm adsorpsi

\begin{tabular}{ccccccc}
\hline \multirow{2}{*}{ Pektin } & \multicolumn{3}{c}{ Isoterm Langmuir } & \multicolumn{3}{c}{ Isoterm Freundlich } \\
\cline { 2 - 7 } & $\begin{array}{c}\mathrm{qm}_{\mathrm{m}} \\
(\mathrm{mg} / \mathrm{g})\end{array}$ & $\begin{array}{c}\mathrm{K}_{\mathrm{L}} \\
(\mathrm{L} / \mathrm{mg})\end{array}$ & $\mathrm{R}^{2}$ & $\mathrm{n}$ & $\begin{array}{c}\mathrm{K}_{\mathrm{F}} \\
(\mathrm{mg} / \mathrm{g})\end{array}$ & $\mathrm{R}^{2}$ \\
\hline Kulit jeruk & 3,688 & 0,6145 & 0,956 & $-1,611$ & 16,4855 & 0,9567 \\
Kulit pisang & 4,1684 & 0,5646 & 0,9985 & $-1,526$ & 19,284 & 0,9986 \\
\hline
\end{tabular}

Sumber: Hasil perhitungan data penelitian, (2020)

Dari persamaan Freundlich diperoleh nilai n yang menunjukkan derajat nonlinearitas antara koefesien larutan adsorpsi, dimana penyimpangan linearitas adsorpsi biasanya digunakan untuk mengetahui tingkat kebenaran suatu adsorpsi [19]. Apabila nilai $\mathrm{n}<1$ maka proses adsorpsi merupakan proses fisiosorpsi dan sebaliknya jika $\mathrm{n}>1$ maka adsorpsi yang terjadi merupakan proses kimiasorpsi [20]. Pada Tabel 4 didapat nilai $n$ kulit jeruk dan kulit pisang sebesar -1,611 dan -1,526. Hal ini menunjukkan bahwa proses adsorpsi terjadi secara fisiosorpsi. Dari persamaan isoterm Langmuir dapat ditentukan nilai qm yang merupakan kapasitas adsorpsi lapisan tunggal (monolayer) [21]. Nilai qm yang didapat untuk pektin kulit jeruk dan pektin kulit pisang sebesar 3,688 dan 4,1684 mg/g. 


\section{Kesimpulan}

Hasil penelitian menunjukkan bahwa kondisi optimum yaitu pada waktu kontak 150 menit dengan penambahan massa pektin $50 \mathrm{mg}$ dengan efisiensi adsorpsi untuk pektin kulit jeruk sebesar 88,096\% dan untuk pektin kulit pisang sebesar 99,428\%. Berdasarkan nilai koefisien determinasi $\mathrm{R}^{2} \geq 0,9$ maka persamaan Langmuir dan Freundlich dapat diterapkan pada adsorpsi logam Fe menggunakan pektin kulit jeruk dan kulit pisang.

\section{Referensi}

[1] Irhamni, S. Pandia, E. Purba, and W. Hasan, "Kandungan Logam Berat pada Air Lindi Tempat Pembuangan Akhir ( TPA ) Sampah Kota Banda Aceh," Pros. Semin. Nas. Pascasarj., vol. 3, no. 1, pp. 19-22, 2017.

[2] E. Puspita, M. Idris, A. Ali, S. Mutia, and L. Rhusmana, "Pemanfaatan Pektin dari Daun Cincau Hijau ( Premna oblongifolia merr ) sebagai Biosorben Logam Fe,” Polban, pp. 83-88, 2017.

[3] N. Solika, M. Napitupulu, T. Gonggo, and H. Pembahasan, "Bioadsorpsi Pb(II) Menggunakan Kulit Jeruk Siam,” vol. 6, no. August, pp. 160-164, 2017.

[4] M. Tahir, I. Safitri, and A. Suhaenah, "Analisis Pektin Albedo Buah Jeruk Pamelo sebagai Adsorben Logam Berat Timbal ( $\mathrm{Pb}$ ), Kadmium ( $\mathrm{Cd}$ ) dan Tembaga ( $\mathrm{Cu}$ )," J. Farm. Galen., vol. 5, no. 2, pp. 158-165, 2019.

[5] E. E. Santos, R. C. Amaro, C. C. Bustamante, and M. H. Guerra, "Food Hydrocolloids Extraction of pectin from agroindustrial residue with an ecofriendly solvent: use of FTIR and chemometrics to differentiate pectins according to degree of methyl esterification," vol. 107, no. March, 2020.

[6] Wusnah, Zulnazri, and Sulastri, "Jurnal Teknologi Kimia Unimal Pengaruh pH dan Waktu Ekstraksi Terhadap Karakteristik Pektin dari Kulit Coklat," J. Teknol. Kim. Unimal, vol. 4, no. 2, pp. 27-35, 2015.

[7] A. Muslim, S. D. Said, G. S. Hariati, S. F. Karina, F. M. Djuned, and R. Mulyawan, “Adsorption of $\mathrm{Cu}$ ( Ii ) Ions in Aqueous Solution Onto Limonia Acidissima Shell- based Activated Carbon: Kinetic and Isotherm Studies," vol. 21, no. 3, pp. 129-136, 2017.

[8] A. Munajad, C. Subroto, and Suwarno, "Fourier Transform Infrared ( FTIR ) Spectroscopy Analysis of Transformer Paper in Mineral Oil-Paper Composite Insulation under Accelerated," $J$. energies, vol. 11, 2018.

[9] J. Latupeirissa, E. G. Fransina, and M. Tanasale, "Extraction and Characterization Of Pectin From The Oranges Peel Of Kisar ( Citrus sp .)," Indones. J. Chem., vol. 7, no. 1, pp. 53-60, 2019.

[10] T. Anh, T. Dao, H. K. Webb, and F. Malherbe, "Optomisation of pectin extraction from fruit peels by response surface method: conventional versus microwave-assisted heating," Jounal Pre-proof, p. 106475, 2020.

[11] F. Jubilate, T. A. Zaharah, and I. Syahbanu, "Pengaruh Aktivasi Arang dari Limbah Kulit Pisang Kepok sebagai Adsorben Besi (II) pada Air Tanah,” JKK, vol. 5, no. 4, pp. 14-21, 2016.

[12] N. Fatmawati, T. Usman, and T. A. Zahara $l$, "Bioadsorpsi Fe ( II ) oleh Kulit Buah Jeruk Citrus nobilis Lour. var microcarpa Termodifikasi $\mathrm{Ca}(\mathrm{OH}) 2$," Indones. J. Pure Appl. Chem., vol. 1, no. 3, pp. 98-113, 2018.

[13] P. Takarani, S. F. Novita, and R. Fathoni, "Pengaruh massa dan waktu adsorben selulosa dari kulit jagung terhadap konsentrasi penyerapan," pp. 117-121, 2019.

[14] A. Rizki, E. Syahputra, S. Pandia, and Halimatuddahliana, "Pengaruh Wajtu Kontak dan Massa Adsorben Biji Asam Jawa (Tamarindus indica) dengan Aktivator H3PO4 terhadap Kapasitas Adsorpsi Zat Warna Methylene Blue,” J. Tek. Kim. USU, vol. 08, no. 2, pp. 54-60, 2019.

[15] Y. Prasetiowati and T. Koestiari, "kapasitas Adsorpsi Bentonit Teknis sebagai Adsorben Ion Cd 2+," Unesa J. Chem., vol. 3, no. 3, pp. 194-200, 2014.

[16] A. Poursaeidesfahani, E. A. Garcia, M. Lange, A. Torres, M. Rigutto, N. Nair, F. Kapteijn, J. Gascon, D. Dubbeldam, and T. J. Vlugt "Prediction of adsorption isotherms from breakthrough curves," Microporous Mesoporous Mater., vol. 277, no. March 2018, pp. 237-244, 2019.

[17] I. D. G. D. P. Kusuma, N. M. Wiratini, and I. G. L. Wiratma, "Isoterm Adsorpsi Cu 2+ oleh Biomassa Rumput Laut Eucheuma Spinosum," e-journal Kim. visvitalis, vol. 2, pp. 1-10, 2014.

[18] Masruhin, R. Rasyid, and S. Yani, "Penjerapan Logam Berat Timbal ( Pb ) dengan Menggunakan Lignin Hasil Isolasi Jerami Padi,” J. Chem. Process Eng., vol. 03, no. 01, pp. 11-20, 2018.

[19] I. W. Sutapa, V. Petrus, D. Siahay, and M. F. J. D. P. Tanasale, "Adsorpsi Ion Logam Cu $2+$ Pada Pektin Dari Kulit Pisang Tongka Langit ( Musa Speices Van Balbisiana ),” Indones. J. Chem., pp. 
72-77, 2014.

[20] A. Larasati and S. Notodarmojo, "Equilibrium and Kinetics of Orthophosphate Removal from Aqueous Phase with Adsorption-Desorption Methods," vol. 20, pp. 38-47, 2014.

[21] L. Hermida, I. Lestari, and J. Agustian, "Silika Berpori dari Kaolin Alam Lampung dan Kajian Aplikasinya terhadap Adsorpsi Rhodamin B Porous Silica from Lampung Natural Kaolinite and Its Application Study to Rhodamine B Adsorption," Pros. Saintiks FTIK UNIKOM, 2017. 